\title{
Motivasi Belajar Untuk Siswa : Jaga Sikapmu, Semangatmu Untuk Meraih Prestasi Dimasa Yang Akan Datang
}

\author{
Rahmi Hermawati ${ }^{*}$, Rima Handayani ${ }^{2}$, Amthy Suraya ${ }^{3}$, Veritia ${ }^{4}$, \\ Eni Puji Astuti ${ }^{5}$ \\ 1,2,3,4,5 Program Studi Manajemen, Fakultas Ekonomi, Universitas Pamulang \\ Jl. Surya Kencana No.1, Pamulang Barat, Kec. Pamulang \\ Kota Tangerang Selatan, Banten 15417 \\ *Penulis Korespodensi: rahmi_herma@yahoo.com \\ DOI : 10.32672/btm.v1i4.1725
}

\begin{abstract}
ABSTRAK
Tujuan dari kegiatan Pengabdian Masyarakat adalah melaksanakan salah satu Tri Dharma Perguruan Tinggi. Selain itu diharapkan dengan kegiatan Pengabdian Masyarakat tersebut keberadaan Pergururan Tinggi dapat memberikan kontribusi besar kepada pengembangan dan penerapan keilmuan kepada masyarakat. Metode yang digunakan dalam Pengabdian Masyarakat ini berupa ekspositori yaitu penyampaian materi secara verbal dan inquiry yaitu pembelajaran yang menekankan pada proses berfikir kritis dan analitis terkait motivasi belajar untuk siswa tentang "Motivasi belajar siswa : jaga sikapmu, semangatmu untuk meraih prestasi dimasa yang akan datang". Hasil Pengabdian Masyarakat yang diperoleh adalah bertambhanya keilmuan bagi Siswa dan siswi SMKN 2 Tagerang Selatan, dan memotivasi untuk belajar. Ilmu yang diperoleh Pada Kegiatan Pengabdian Masyarakat ini diharapkan mampu memberikan semangat baru bagi kita dalam menyampaikan materi dan motivasi serta berkontribusi bagi siswa dan siswi untuk memotivasi belajar yang positif, prilaku yang membangun Baik di lingkungan masyarakat dan keluarga.

Kata Kunci: Motivasi Belajar
\end{abstract}

\begin{abstract}
The aim of Community Service activities is to carry out one of the Higher Education Tri Dharma. In addition, it is expected that through the Community Service activities, the existence of Higher Education can contribute greatly to the development and application of knowledge to the community.The method used in this Community Service is expository namely the delivery of material verbally and inquiry that is learning that emphasizes the process of critical and analytical thinking related to learning motivation for students about "Student learning motivation: keep your attitude, your enthusiasm for achievement in the future".The results of community service are scientific advances for students of South Tagerang 2 vocational schools, and motivate them to study. The knowledge gained in Community Service Activities is expected to be able to provide new enthusiasm for us in conveying material and motivation as well as
\end{abstract}


Rahmi Hermawati, Rima Handayani, Amthy Suraya, Veritia, Eni Puji Astuti

contributing for students to motivate positive learning, constructive behavior in both the community and family environment.

Keywords: Learning Motivation

\section{PENDAHULUAN}

Belajar adalah aktivitas yang merupakan hal yang utama harus dilakukan oleh setiap siswa dan siswi di sekolah, sebuah prestasi dimulai dari menjaga semangat belajar yang terus menerus harus ada didalam diri siswa.

Masalah- masalah internal baik dari lingkungan keluarga atau lingkungan rumah menjadi kendala utama dalam menjaga kestabilan belajar siswa. Dalam hal ini peran orang tua dan guru menjadi point penting sebagai orang yang memberi dukungan tersebut.

Motivasi belajar bisa berasal dari diri sendiri ataupun orang lain, motivasi belajar yang tinggi akan dicapai ketika siswa menyadari betapa pentingnya nilai sebuah penghargaan, kebanggan, dan nilai kepercayaan diri. Hampir 75\% siswa yang berprestasi mempunyai semangat dan daya juang yang tinggi untuk meraih kesuksesan dimasa yang akan datang.

\section{METODE PELAKSANAAN KEGIATAN}

Metode yang digunakan dalam Pengabdian Masyarakat ini berupa ekspositori yaitu penyampaian materi secara verbal dan inquiry yaitu pembelajaran yang menekankan pada proses berfikir kritis dan analitis terkait motivasi belajar untuk siswa tentang "Motivasi belajar siswa: aga sikapmu, semangatmu untuk meraih prestasi dimasa yang akan datang".

\section{HASIL DAN PEMBAHASAN}

Kata motivasi berasal dari kata "motif', yang berarti alasan melakukan sesuatu, sebuah kekuatan yang menyebabkan seseorang bergerak melakukan suatu kegiatan. Dalam Kamus Besar Bahasa Indonesia, (Depdikbud, 1996:593) motivasi didefinisikan sebagai dorongan yang timbul pada diri seseorang sadar atau tidak sadar untuk melakukan suatu tindakan dengan tujuan tertentu.Sondang P. Siagian (2004:138), memberikan definisi motivasi sebagai daya dorong yang mengakibatkan seseorang mau dan rela untuk mengerahkan kemampuan, tenaga dan waktunya dalam rangka pencapaian tujuan yang telah ditentukan sebelumnya.

Dengan demikian motivasi merupakan usaha-usaha yang dapat menyebabkan seseorang atau kelompok orang tertentu bergerak untuk melakukan sesuatu keinginan mencapai tujuan yang dikehendakinya atau mendapat kepuasan dengan perbuatannya. Untuk itu, motivasi adalah suatu proses internal yang mengaktifkan, membimbing, dan mempertahankan perilaku dalam rentang waktu tertentu. Dengan kata lain, motivasi adalah apa yang membuat kita berbuat, membuat kita tetap berbuat dan menentukan ke arena mana yang hendak kita perbuat. 
BAKTIMAS

Jurnal Pengabdian pada Masyarakat
Vol. 1, No. 4,

Desember 2019
eISSN 2685-113x

pISSN 2685-0303

Motivasi dapat dikatakan sebagai pengaruh kebutuhan dan keinginan pada intensitas dan arah seseorang yang menggerakkan orang tersebut untuk mencapai tujuan dari tingkat tertentu. Menurut Mc. Donald yang dikutip oleh Oemar Hamalik (2002:1973), motivasi adalah suatu perubahan energi di dalam diri pribadi seseorang yang ditandai dengan timbulnya afektif, dan reaksi untuk mencapai tujuan, juga sebagai dorongan dari dalam diri seseorang dan dorongan ini merupakan motor penggerak.

Oleh karena itu, motivasi sebagai proses batin atau proses psikologis yang terjadi pada diri seseorang sangat dipengaruhi oleh faktor eksternal (lingkungan), dan faktor internal yang melekat pada setiap orang (pembawaan), tingkat pendidikan, pengalaman masa lalu, keinginan atau harapan masa depan.

Berdasarkan pengertian di atas, maka dapat disimpulkan bahwa motivasi adalah suatu proses perubahan tenaga dalam diri individu yang memberi kekuatan baginya untuk bertingkah laku (dengan giat belajar) dalam usaha mencapai tujuan belajarnya.

Sedangkan belajar merupakan proses dasar dari perkembangan hidup manusia, dengan belajar manusia melakukan perubahan-perubahan kualitatif individu sehingga tingkah lakunya berkembang. Semua aktivitas dan prestasi hidup manusia tidak lain adalah hasil dari belajar, karena seseorang hidup dan bekerja menurut apa yang telah dipelajari. Belajar itu bukan hanya sekedar pengalaman, belajar adalah suatu proses, bukan suatu hasil. Oleh karena itu, belajar berlangsung aktif dan integratif dengan menggunakan berbagai bentuk perbuatan untuk mencapai hasil.

W.S Winkel (1996:53) mengatakan, bahwa belajar adalah suatu aktivitas mental/psikis yang berlangsung dalam interaksi aktif dengan lingkungannya, yang menghasilkan perubahan-perubahan, pengetahuan, pemahaman, keterampilan dan nilai sikap, serta perubahan itu bersifat secara relatif konstan dan tetap. Sedangkan yang dimaksud motivasi belajar adalah keinginan yang mengaktifkan, menggerakkan, menyalurkan dan mengarahkan sikap dan perilaku individu untuk belajar.

\section{Cara Meningkatkan Motivasi Belajar Menggunakan metode dan kegiatan belajar mengajar yang beragam}

Melakukan kegiatan yang sama secara terus-menerus tentu akan menimbulkan rasa bosan yang berlebihan, hal ini tentu dapat menurunkan semangat belajar para siswa. Apabila siswa sudah merasa bosan tentu akan mengakibatkan terganggunya proses belajar mengajar. Disinilah Anda sebagai guru harus bertindak, berikanlah variasi belajar sehingga para siswa bisa tetap termotivasi dan konsentrasi dalam belajar. Sesekali Anda bisa mencoba metode belajar yang berbeda seperti membuat pembagian peran, studi kasus, simulasi, debat, transfer pengetahuan secara singkat, diskusi, presentasi dengan audio-visual dan kerja kelompok kecil

\section{Cara Meningkatkan Motivasi Belajar Jadikan siswa sebagai peserta aktif}

Contoh upaya untuk meningkatkan motivasi belajar siswa yang kedua adalah dengan menjadikan siswa sebagai peserta yang aktif. Di usia siswa yang masih muda tentu kehidupan mereka sepenuhnya hanya dengan melakukan kegiatan, menulis, belajar, berpertualang, menciptakan sesuatu hal baru, menyelesaikan suatu masalah, serta mendesain. Ketika berada di sekolah, jangan pernah menjadikan siswa sebagai peserta pasif di kelas. Kenapa demikian? Karena hal tersebut dapat menurunkan minat dan mengurangi rasa keingintahuannya. Gunakanlah metode belajar yang aktif dengan 
Rahmi Hermawati, Rima Handayani, Amthy Suraya, Veritia, Eni Puji Astuti

memberikan siswa tugas berupa simulasi penyelesaian suatu masalah untuk menumbuhkan motivasi dalam belajar. Jangan berikan jawaban apabila tugas tersebut dirasa sanggup dilakukan oleh siswa.

\section{Cara Meningkatkan Motivasi Belajar Menciptakan suasana kelas yang kondusif}

Contoh motivasi belajar siswa selanjutnya adalah dengan menciptakan suasana kelas yang kondusif. Karena kelas yang aman dan tidak mendikte umumnya akan membuat siswa merasa didukung untuk berusaha. Hal ini akan berpengaruh terhadap minat belajarnya dan akan menumbuhkan motivasi belajar secara tidak langsung. Apabila siswa belajar di suatu kelas yang kondusif, maka siswa cenderung terdorong untuk terus mengikuti proses belajar.

\section{Cara Meningkatkan Motivasi Belajar Berikan tugas yang proporsional}

Segala tugas di kelas dan pekerjaan rumah tidak selalu bisa disetarakan dengan nilai. Jangan hanya berorientasi pada nilai dan coba penekanan pada penguasaan materi. Mengapa demikian? Karena hal tersebut dapat menurunkan semangat siswa yang kurang mampu memenuhi standar dan berakibat siswa yang bersangkutan merasa dirinya gagal. Usahakan untuk menggunakan mekanisme nilai seperlunya saja, dan mulailah untuk lebih dekat dengan siswa dengan memperhatikan kelebihan dan kekurangan mereka, serta apa yang bisa mereka tingkatkan. Disarankan untuk memberikan komentar yang jelas agar siswa pun dapat langsung memperbaiki tugas mereka apabila dirasa belum cukup.

\section{Cara Meningkatkan Motivasi Belajar}

Berikan petunjuk kepada siswa agar sukses dalam belajarJangan pernah membiarkan siswa berjuang sendiri dalam belajar. Sebagai orang tua mereka di sekolah, sampaikanlah pada mereka apa saja yang perlu mereka lakukan. Dan yang terpenting, buatlah mereka yakin bahwa mereka bisa sukses dan bagaimana cara

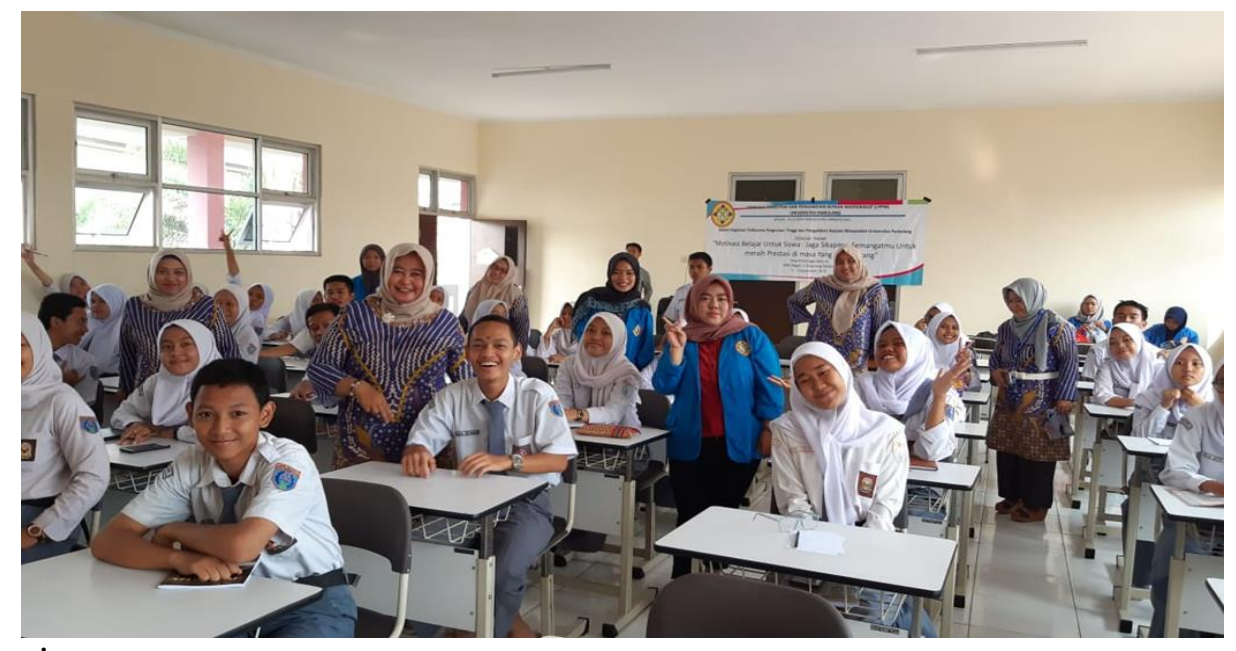

mencapainya. 
BAKTIMAS

Jurnal Pengabdian pada Masyarakat
Vol. 1, No. 4,

Desember 2019
eISSN 2685-113x

pISSN 2685-0303

\section{Cara Meningkatkan Motivasi Belajar Antusias dalam mengajar}

Antusiasme seorang guru dalam mengajar ternyata salah satu faktor yang penting untuk menumbuhkan motivasi belajar dalam diri para siswa. Bila Anda terlihat lesu dan kurang bersemangat maka para siswa juga akan menunjukkan hal yang demikian. Upayakan untuk selalu tampil ceria dan bersemangat serta antusias di depan kelas.

\section{Cara Meningkatkan Motivasi Belajar Pemberian penghargaan untuk memotivasi}

Pemberian penghargaan seperti nilai tambahan, hadiah kecil ketika mendapatkan pencapaian yang baik mungkin juga cukup efektif untuk menumbuhkan semangat belajar siswa.

\section{Cara Meningkatkan Motivasi Belajar Kenali minat siswa}

Meskipun berada di kelas yang sama, setiap siswa tentu memiliki kepribadian yang berbeda-beda. Disinilah tugas Anda sebagai guru, pahamilah siswa Anda dengan selalu memberikan tanggapan terhadap materi, minat, cita-cita, harapan serta kekhawatiran mereka. Pergunakanlah berbagai contoh dalam pembelajaran yang ada kaitannya dengan minat mereka untuk membuat mereka tetap termotivasi dalam belajar.

\section{Cara Meningkatkan Motivasi Belajar Peduli dengan siswa}

Umumnya, para siswa akan menunjukkan minat dan motivasi belajar mereka kepara guru yang memiliki perhatian kepada mereka. Cobalah membangun hubungan yang positif dengan para siswa. Caranya mudah, Anda bisa menceritakan kisah hidup Anda yang positif pada mereka.

\section{Cara Meningkatkan Motivasi Belajar Harga kesuksesan dan keteladanan}

Dan yang terakhir, hindari komentar negatif terhadap kelakuan buruk dan performa rendah yang ditunjukan oleh siswa Anda. Akan lebih baik jika Anda memberikan apresiasi bagi siswa yang menunjukan kelakuan dan kinerja yang baik. Pujian positif dan dorongan secara tidak langsung akan menjadi penggerak yang turut berpengaruh dan memberikan aspirasi bagi siswa yang lain untuk berprestasi.

\section{PENUTUP}

Harapan kami dengan pengabdian ini dapat membuka wawasan dari yaitu yaitu SMKN 2 TANGSEL, Jl. Mushola Nurul Huda Pamulang Tangerang Selatan yang akan menghadapi era globalisasi . Materi yang kami berikan yaitu Motivasi belajar untuk siswa da siswi , sekaligus bahan kajian dan masukan bagi masyarakat ( guru, orang tua peserta didik SMKN 2 Tangerang,) tersebut untuk dapat mengimplementasikannya dalam kehidupan sehari-hari, sehingga dapat membantu dan meningkatkan motivasi belajar dan keperibadian yang yang akan sangat bermanfaat dalam kehidupan mereka pada masa yang akan datang. 
Rahmi Hermawati, Rima Handayani, Amthy Suraya, Veritia, Eni Puji Astuti

\section{DAFTAR PUSTAKA}

Aritonang, Keke T. 2008. "Minat dan Motivasi dalam Meningkatkan Hasil Belajar Siswa". Jurnal Pendidikan Penabur, 7(10): 11-21.

Dinar, Barokah. 2011. Indikator Minat Belajar Siswa. (online). (http://pedomanskripsi.blogspot.com/2011/07/indikator, diakses tanggal 10 Desember 2016).

Hamzah, Moh dan Ismail. 2009. "Pengaruh Lingkungan dan Motivasi Belajar Siswa terhadap Hasil Belajar Matematika Siswa di Kejar Paket C PKBM Sultan Agung Kesambi Kota Cirebon". Jurnal EduMa, 1(2): 101-112.

Manula, Yunitasari. 2013."Masalah Belajar Peserta Didik” (online), (http://yunitasarimanula.wordpress.com/2013/03/19/cara-menentukan-siswayang-mengalami-masalah-belajar, diakses tanggal 12 Desember 2016).

Sunarsi, D. (2018). Analisis Motivasi Kerja Tenaga Pendidik Sukarela Pada Pusat Kegiatan Belajar Masyarakat (PKBM) Bimasda Kota Tangerang Selatan. Kreatif: Jurnal Ilmiah Prodi Manajemen Universitas Pamulang, 6(2), 53-65. 